\title{
Dynamics of Primary Productivity and Oceanographic Parameters under Influence of the Amazon River Plume
}

\author{
Amanda Otsuka1, Fernando Feitosa1, Moacyr Araújo1, Dóris Veleda1, \\ Maria da Gloria Silva Cunha ${ }^{1}$, Nathalie Lefévre ${ }^{2}$, Felipe Gaspar ${ }^{1}$, Manuel Flores Montes ${ }^{1}$, \\ Gislayne Borges ${ }^{1}$, Carlos Noriega ${ }^{1 *}$ \\ ${ }^{1}$ Department of Oceanography, Federal University of Pernambuco, Recife, Brazil \\ ${ }^{2}$ IRD-LOCEAN, Sorbonne Universités (Université Pierre et Marie Curie-CNRS-MNHN), Paris, France \\ Email: *carlos.delnor@gmail.com
}

How to cite this paper: Otsuka, A., Feitosa, F., Araújo, M., Veleda, D., Cunha, M. da G.S., Lefévre, N., Gaspar, F., Montes, M.F., Borges, G. and Noriega, C. (2018) Dynamics of Primary Productivity and Oceanographic Parameters under Influence of the Amazon River Plume. Open Journal of Ecology, 8, 590-606.

https://doi.org/10.4236/oje.2018.811035

Received: October 24, 2018

Accepted: November 25, 2018

Published: November 28, 2018

Copyright $(9) 2018$ by authors and Scientific Research Publishing Inc. This work is licensed under the Creative Commons Attribution International License (CC BY 4.0).

http://creativecommons.org/licenses/by/4.0/

\begin{abstract}
The watershed of the Amazon River discharges about $120,000 \mathrm{~m}^{3} \cdot \mathrm{s}^{-1}$ of freshwater into the adjacent platform and oceanic region. The aim of this work was to analyze the distribution of oceanographic parameters, chlorophyll a and primary productivity under the influence of the Amazon River plume, during the period of greatest extension of the Amazon plume. Collections were carried out in September 14 in 16 stations including continental platform and oceanic region. It was possible to observe superficial currents along the coast in the northwest direction, but with less intensity and currents with greater speeds towards the east due to the North Brazil Current retroflexion at this time of the year, transporting the plume to the central Atlantic Ocean. The spatial influence of the plume was observed in the salinity, which ranged from 28 to 36.75 , although the high precipitation in the region may also have contributed as a source of freshwater. However, the sampled region showed strong negative linear correlation of silicate, chlorophyll a and primary productivity with salinity. The primary productivity values ranged from 0.04 to $18.81 \mathrm{mg} \mathrm{C} \mathrm{m}^{-3} \mathrm{day}^{-1}$, whereas chlorophyll a concentrations ranged from $0.15 \mathrm{mg} \cdot \mathrm{m}^{-3}$ to $1.83 \mathrm{mg} \cdot \mathrm{m}^{-3}$, decreasing their values as they move away from the coast. The Amazon River plume can reach and influence the oceanographic and biological parameters in a large area of this oligotrophic region. However, the results also suggest that the export of material from the adjacent coastal region is another determinant of the region's productivity.
\end{abstract}

\section{Keywords}

Amazon River Plume, Continental Shelf, Oceanic Region, Environmental 
Variables, Phytoplankton Biomass, Primary Productivity

\section{Introduction}

Primary production and chlorophyll a concentrations are always dependent on synergistic effects among meteorological, physical, chemical and biological factors that limit or stimulate the activity of photosynthetic planktonic organisms [1] [2]. Environmental alterations that cause changes in parameters such as light, temperature, salinity, $\mathrm{pH}$ and nutrient availability directly affect biomass, density, community structure and primary productivity [3].

Fluvial inflows carry significant amounts of nutrients, affecting especially continental platform regions, which act as a final recipient of these waters and have a major impact on the phytoplankton community structure. The dynamic structure resulting from this process is a mass of floating water with density lower than that of coastal waters, called a river plume [4] [5] [6] [7].

The watershed of the Amazon River discharges about $120,000 \mathrm{~m}^{3} \cdot \mathrm{s}^{-1}$ of freshwater, but is also responsible for about $30 \%$ of the freshwater flow to the Atlantic Ocean [8] [9]. It presents a surface plume of approximately $3-10 \mathrm{~m}$ thick, which covers an area that varies between $2.31 \times 10^{6} \mathrm{~km}^{2}$ and $5.26 \times 10^{6} \mathrm{~km}^{2}$. In this way, it significantly influences the flow of nutrients, and other suspended materials, interfering in the biogeochemistry of many elements present along the continental platform [10] [11] [12] [13]. Due to this influence, the plume has a differentiated phytoplankton structure in relation to the adjacent oceanic region, with high concentrations of photosynthetic pigments [14].

Previous works in the Western Tropical North Atlantic ([11] [14]-[20], among others) have reported that the influence of the Amazon River plume has implications on the distribution of phytoplankton productivity, chlorophyll a and on the hydrological characteristics in the adjacent platform and oceanic zone.

Previous works in the Western Tropical North Atlantic [11] [15] [16] [17] have reported that the influence of the Amazon River plume has implications on the distribution of phytoplankton productivity, chlorophyll $a$ and on the hydrological characteristics in the adjacent platform and oceanic zone. [7] [14] [18] quantified the phytoplankton biomass and productivity primary and reported the strong related to group of diatom in plume waters [19] [20]. [1] [20] classified through chlorophyll $a$ as the areas of influence of the river are eutrophic $\left(1.67 \mathrm{mg} \cdot \mathrm{m}^{-3}\right)$, while [21] reported its influence on the planktonic community along the Amazon River-Ocean Continuum in the period of minimum discharge.

The aim of this study was to analyze the distribution of chlorophyll $a$ and primary productivity in the northern region of Brazil, evaluating factors that influence net primary productivity and environmental parameters in plume waters and adjacent ocean waters during the period of greatest spatial extension of the 
Amazon River plume in the Atlantic Ocean.

\section{Materials and Methods}

\subsection{Description of the Study Area}

The study area is characterized by humid tropical climate (Köppen type AF), with high and constant rainfall $\left(>60 \mathrm{~mm} / \mathrm{month}^{-1} ;>1500 \mathrm{~mm} \cdot \mathrm{year}^{-1}\right)$ and temperature $>20^{\circ} \mathrm{C}$. The discharge of water from the Amazon River varies seasonally, with peak flow in May/June and minimum flow in October/November [22] [23] [24]. Despite the great fluvial contribution that interferes in the movement of waters in the platform, physical forces such as tides, rainfall and winds are determining factors. The dominant trade winds are more intense from December to April, increasing the wave energy and modifying the flow of the Amazon on the platform [25].

The North continental platform has maximum length of $320 \mathrm{~km}$ at the mouth of the Amazon River [24] [26] [27]. The near-surface circulation is characterized by the presence of the North Brazil Current (NBC) and its sub-surface component, the North Brazil Sub-current(NBSC), formed from the bifurcation of the South Equatorial Current (SEC) [28] [29]. In the period from February to June, the NBC shows a continuous flow along the Brazilian coast, in the northwest direction. From July to January, the northward migration of the trade winds promotes the retroflexion of the $\mathrm{NBC}$, crossing the Equatorial Line and feeding the North Equatorial Counter-current (NECC), between latitudes $5^{\circ} \mathrm{N}$ and $10^{\circ} \mathrm{N}$ [7] [30] [31] [32].

\subsection{Sampling}

\subsubsection{Sample Data}

Collections were carried out in the "Camadas Finas V" oceanographic campaign held in September/2014 at 16 stations along the continental shelf of the Amazon and adjacent oceanic region, aboard of the NHo 38 ship ("Cruzeiro do Sul" hydro-oceanographic ship), which belongs to the Brazil Navy, at two depths (surface and DCM-depth chlorophyll maximum) (Figure 1).

At each station, surface vertical profiles (up to $400 \mathrm{~m}$ ) of hydrodynamic, physical, chemical and biological parameters were measured. Hydrodynamic parameters were determined through an ADCP Hull Profiler, while salinity, temperature and depth were measured using a Seabird 25 CTD profiler.

In addition, water samples were collected with Niskin bottles at the two depths selected for the determination of dissolved oxygen, nutrients, chlorophyll $a$ and phytoplankton productivity.

\subsubsection{Preprocess of the Data}

Dissolved oxygen analyses were determined by the modified Winkler method described in [33]; nitrite and nitrate were analyzed by the method of [33] and ammonia, silicate and phosphate, following standard colorimetric methods [34]. 


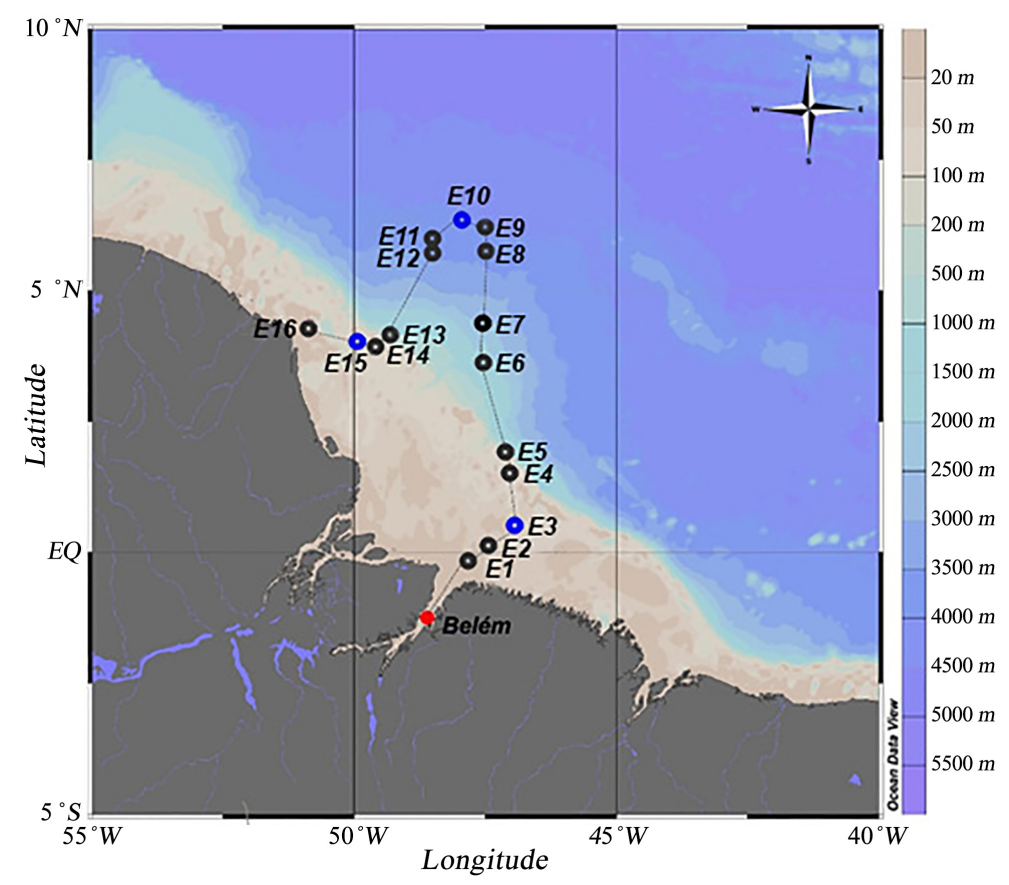

Figure 1. Positions of the 16 stations sampled along the ship track during the Camadas Finas V cruise (CFV), September 2014.

For the total chlorophyll $a$ analysis, filtrations were performed using Whatman GF/C filters of $47 \mathrm{~mm}$ in diameter. The filtrate volume ranged from 1 to $3 \mathrm{~L}$ depending on the amount of material trapped in the filter. After this procedure, chlorophyll a was extracted in $90 \%$ acetone for 24 hours at $-18^{\circ} \mathrm{C}$. In a similar manner to chlorophyll a determination, chlorophyll a corresponding to a fraction $<20 \mu \mathrm{m}$ was also determined. For this fractionation, samples passed through a $20 \mu \mathrm{m}$ mesh prior to filtration. Phytoplankton biomass was quantified through the chlorophyll a concentration using the UNESCO spectrophotometric method [35] and calculations were based on the [36] equation, and results were expressed in $\mathrm{mg} \cdot \mathrm{m}^{-3}$.

At each station and measurement depth, phytoplankton productivity was determined through the Steemann-Nielsen ${ }^{14} \mathrm{C}$ method using a Dupont $10 \mu \mathrm{Ci}$ $\mathrm{NaHCl}$ ampoule for each three $120 \mathrm{ml}$ borosilicate flasks (one dark and two transparent) and with simulated incubation on the ship for 3 hours and in-situ temperature [37]. After incubation, samples were vacuum filtered on Whatman $47 \mathrm{~mm}$ GF/F filters. Filters were read in the Packard Tri-Carb liquid scintillator from the Oceanographic Institute of the University of São Paulo. Productivity calculations were based on [38], where net primary productivity resulting from the subtraction and gross production and respiration was considered, and the results expressed in $\mathrm{mg} \mathrm{C} \mathrm{m}{ }^{-3} \mathrm{~h}^{-1}$ were later recalculated to $\mathrm{g} \mathrm{C} \mathrm{m}^{-2} \mathrm{~d}^{-1}$. The dissolved inorganic carbon, required for productivity calculations, was measured at the same collection depths and the results are presented in [39].

In addition to data obtained in the sampling, the Tropical Rainfall Measuring Mission (TRMM) daily data [40] (http://precip.gsfc.nasa.gov/; $0.25^{\circ}$ resolution) 
were used to estimate the influence of rain associated with ZCIT in the sampling region. TRMM data corresponding to the sampling days were linearly interpolated to the ship position.

\subsubsection{Statistical Analysis}

For statistical analysis, Pearson's correlation was used to analyze the relationships between variables. Calculations were performed using the software PAST version 3.02 .

\section{Results}

The influence of the Amazon plume on the surface salinity of the sampled region was notorious. Salinity levels ranged from 28 (E16) to 36.8 (E2), with mean value of 34.5 ( \pm 2.73 ). At DMC, values ranged from 35.08 (E16) to 36.07 (E4). Lower salinity values $(<35)$ were observed at stations 11 to 16 (Figure 2$)$; in the other stations, the values found are typical of oceanic areas.

The mean temperature was $27.9^{\circ} \mathrm{C}( \pm 0.71)$ at the surface and $26.7^{\circ} \mathrm{C}( \pm 1.4)$ at DMC. From the CTD profiles, thermocline from 80 to $120 \mathrm{~m}$ in depth was observed (E5 to E9), and at Stations 10 to 13, a shallow thermocline was observed, from about 10 to $30 \mathrm{~m}$ in depth (Figure 2).

From ADCP data, it was possible to observe surface currents along the coast in the northwest direction, but with lower intensity, with mean values between 0.30 and $0.44 \mathrm{~m} \cdot \mathrm{s}^{-1}$ and currents with higher velocity towards the east, showing mean values between 1.30 and $1.37 \mathrm{~m} \cdot \mathrm{s}^{-1}$, in the oceanic region at approximately $6^{\circ}-8^{\circ} \mathrm{N}$ (Figure 3 ).

The concentration of suspended particulate material (SPM) was higher on the surface, at the first stations $(1-5)$, with maximum of $4.95 \mathrm{mg} \cdot \mathrm{L}^{-1}(\mathrm{E} 1)$, with mean value of $2.17 \mathrm{mg} \cdot \mathrm{L}^{-1}( \pm 1.41)$.

The surface dissolved oxygen (DO) value varied from $3.46 \mathrm{ml} \cdot \mathrm{L}^{-1}$ (E13) to 6.46 $\mathrm{ml} \cdot \mathrm{L}^{-1}$ (E16) with mean value of $4.83 \mathrm{ml} \cdot \mathrm{L}^{-1}( \pm 0.68)$. AtDMC, the variation was lower, with minimum value of $3.90 \mathrm{ml} \cdot \mathrm{L}^{-1}$ (E12) and maximum value of 4.88 $\mathrm{ml} \cdot \mathrm{L}^{-1}(\mathrm{E} 8)$, with mean value of $4.7 \mathrm{ml} \cdot \mathrm{L}^{-1}( \pm 0.25)$ (Figure 4$)$.

In relation to nutrients, silicate was the one that stood out, with concentrations ranging from $0.19 \mu \mathrm{mol} \cdot \mathrm{L}^{-1}$ (E6) to $37.20 \mu \mathrm{mol} \cdot \mathrm{L}^{-1}$ (E16) on the surface, with mean value of $6.7 \mu \mathrm{mol} \cdot \mathrm{L}^{-1}( \pm 9.19)$ (Figure 4). In addition, silicate presented a strong negative correlation with salinity. AtDMC, the variation was from $0.37 \mu \mathrm{mol} \cdot \mathrm{L}^{-1}$ (E9) to $10.9 \mu \mathrm{mol} \cdot \mathrm{L}^{-1}$ (E14), with mean value of $3 \mu \mathrm{mol} \cdot \mathrm{L}^{-1}$ $( \pm 2.53)$. The surface DIN values ranged from $0.02 \mu \mathrm{mol} \cdot \mathrm{L}^{-1}$ (E5) to $5.24 \mu \mathrm{mol} \cdot \mathrm{L}^{-1}$ (E13), with mean value of $1.3 \mu \mathrm{mol} \cdot \mathrm{L}^{-1}( \pm 1.43)$, and the variation was 0.02 $\mu \mathrm{mol} \cdot \mathrm{L}^{-1}$ (E3 and E6) and $7.3 \mu \mathrm{mol} \cdot \mathrm{L}^{-1}$ (E8), with mean value of $1.5 \mu \mathrm{mol} \cdot \mathrm{L}^{-1}$ $( \pm 1.84)$. The mean surface phosphate was $0.1( \pm 0.03) \mu \mathrm{mol} \cdot \mathrm{L}^{-1}$ and at DMC, the value was $0.1 \mu \mathrm{mol} \cdot \mathrm{L}^{-1}( \pm 0.04)$. Nitrate was the dominant form of nitrogenous nutrients. In general, nitrogenous nutrients and phosphate presented low values, characteristic of oligotrophic environments.

The total chlorophyll a concentration on the surface ranged from $0.07 \mathrm{mg} \cdot \mathrm{m}^{-3}$ 
(E7) to $1.83 \mathrm{mg} \cdot \mathrm{m}^{-3}$ (E16) with mean value of $0.42 \mathrm{mg} \cdot \mathrm{m}^{-3}( \pm 0.42)$. At DMC, it ranged from $0.18 \mathrm{mg} \cdot \mathrm{m}^{-3}$ (E8) to $0.92 \mathrm{mg} \cdot \mathrm{m}^{-3}$ (E15) with mean value of 0.51 $\mathrm{mg} \cdot \mathrm{m}^{-3}( \pm 0.22)$ (Figure 5). Chlorophyll $<20 \mu \mathrm{m}$ corresponded to $51.56 \%$ and $63.85 \%$ of the total chlorophyll $a$, on the surface and at DMC, respectively.

Station 16 showed the highest primary production values, together with the highest chlorophyll $a$ and silicate values. Productivity had maximum value of $18.81 \mathrm{mg} \mathrm{C} \mathrm{m}^{-3} \mathrm{~h}^{-1}$, followed by E13 $\left(1.58 \mathrm{mg} \mathrm{C} \mathrm{m}^{-3} \mathrm{~h}^{-1}\right)$, E1 $\left(1.44 \mathrm{mg} \mathrm{C} \mathrm{m}^{-3} \mathrm{~h}^{-1}\right)$ and $\mathrm{E} 2,44 \mathrm{mg} \mathrm{C} \mathrm{m}^{-3} \mathrm{~h}^{-1}$ ), all on the surface. At DMC, the maximum value was $1.02 \mathrm{mg} \mathrm{C} \mathrm{m}^{-3} \mathrm{~h}^{-1}$ at station 16 , in the other stations, values were below $1 \mathrm{mg} \mathrm{C}$ $\mathrm{m}^{-3} \mathrm{~h}^{-1}$. The average of all stations sampled on the surface was $2.7 \mathrm{mg} \mathrm{C} \mathrm{m}^{-3} \mathrm{~h}^{-1}$ $( \pm 7.68)$ and $0.4 \mathrm{mg} \mathrm{C} \mathrm{m}^{-3} \mathrm{~h}^{-1}( \pm 0.26)$ at DMC (Figure 5). Phytoplankton productivity was positively correlated with total chlorophyll $a$ and silicate. In addition, these two parameters (productivity primary and silicate) showed a strong negative correlation with surface salinity, that is, these concentrations increase in plume waters (Table 1).

Table 1. Correlation coefficients (r) between PP, Chl (chlorophyll a), Salinity (Sal) and $\mathrm{SiO}_{2}$. The number of observations ( $\mathrm{n}$ ), $\alpha$, $\mathrm{p}$-value (p) and degrees of freedom (df) are also indicated.

\begin{tabular}{|c|c|c|c|c|c|}
\hline & $\mathbf{r}$ & $\mathrm{n}$ & $\alpha$ & $\mathrm{p}$ & df \\
\hline $\mathrm{PP} / C h 1$ & 0.85 & & & & \\
\hline $\mathrm{PP} / S a l$ & -0.74 & & & & \\
\hline $\mathrm{PP} / \mathrm{SiO}_{2}$ & 0.94 & 18 & 0.05 & $<0.05$ & 99 \\
\hline Chl/ $\mathrm{SiO}_{2}$ & 0.84 & & & & \\
\hline $\mathrm{Sal} / \mathrm{SiO}_{2}$ & -0.72 & & & & \\
\hline
\end{tabular}
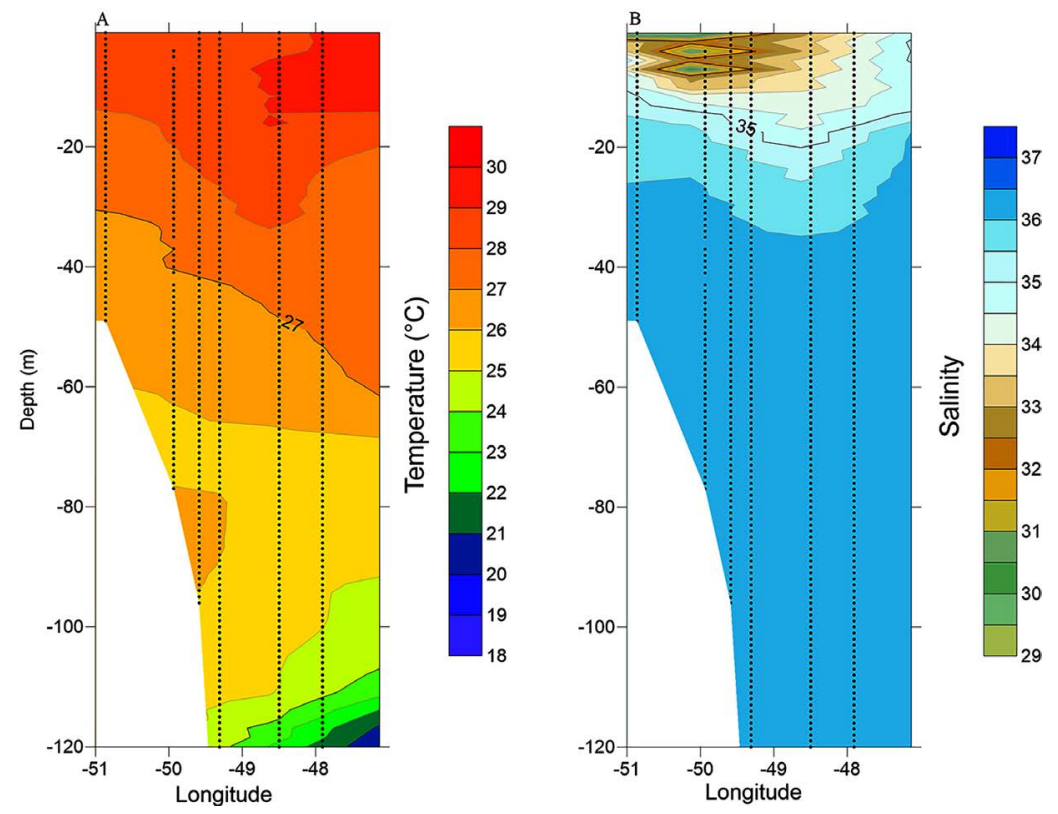

Figure 2. Interpolated vertical profiles of (A) temperature and (B) salinity from sampling stations E10 - E16 during the CFV cruise, September 2014. These stations were the only ones showing freshening at the surface layer. 


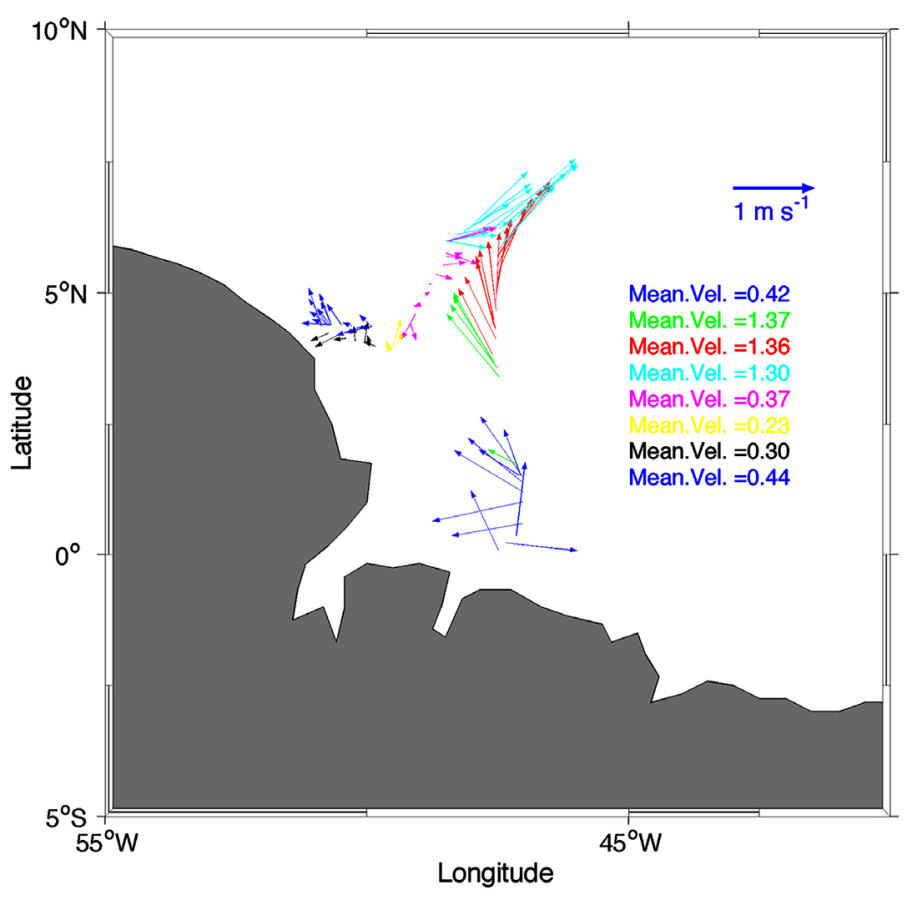

Figure 3. Direction and intensity of the surface layer circulation measured onboard during the CFV cruise, September 2014. Grouped average velocity intensity is also shown (note the color code).
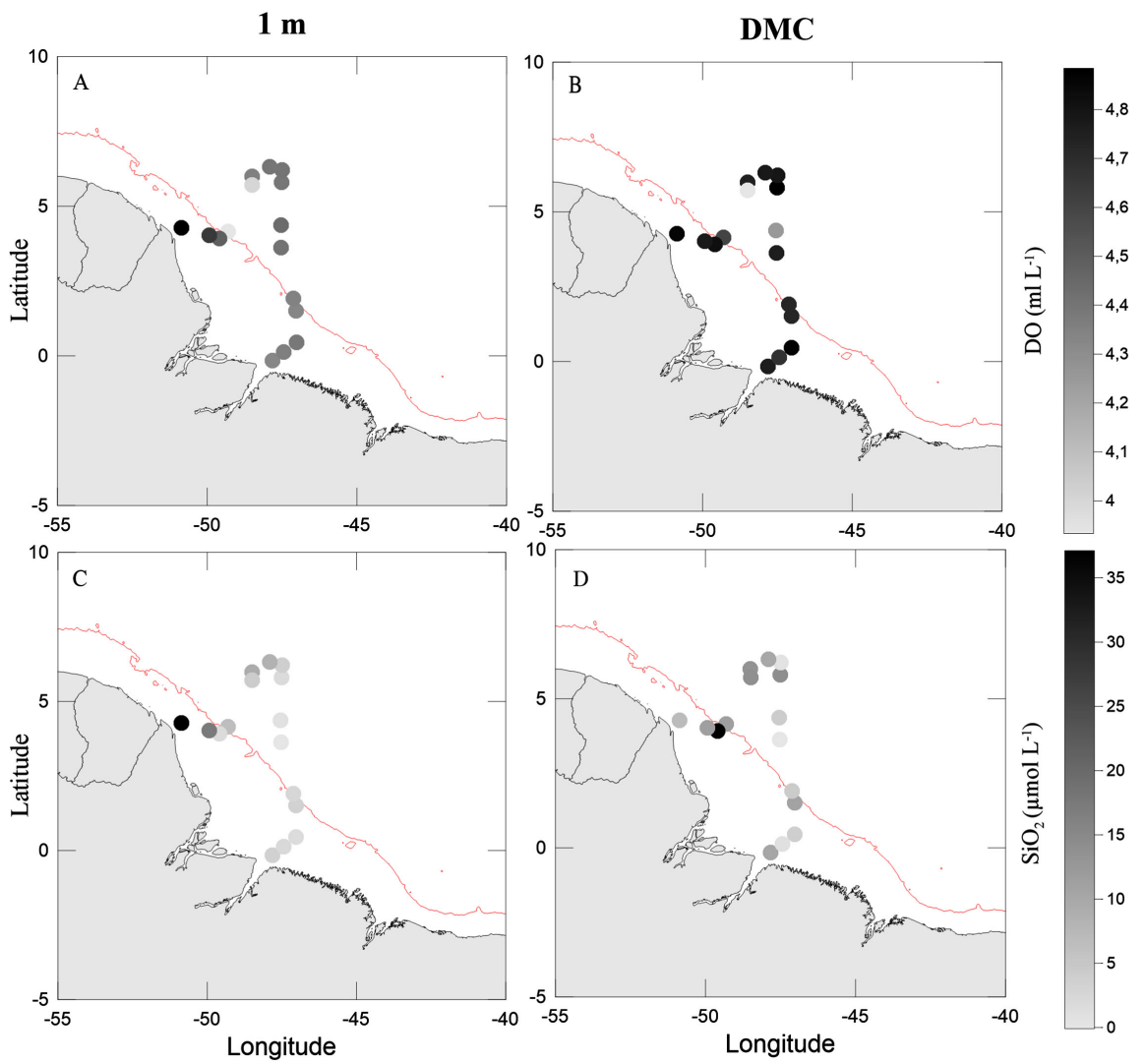

Figure 4. Distribution of (A) DO at surface, (B) DO at DCM, (C) $\mathrm{SiO}_{2}$ at surface and (D) $\mathrm{SiO}_{2}$ at DCM, during the CFV cruise, September 2014. 

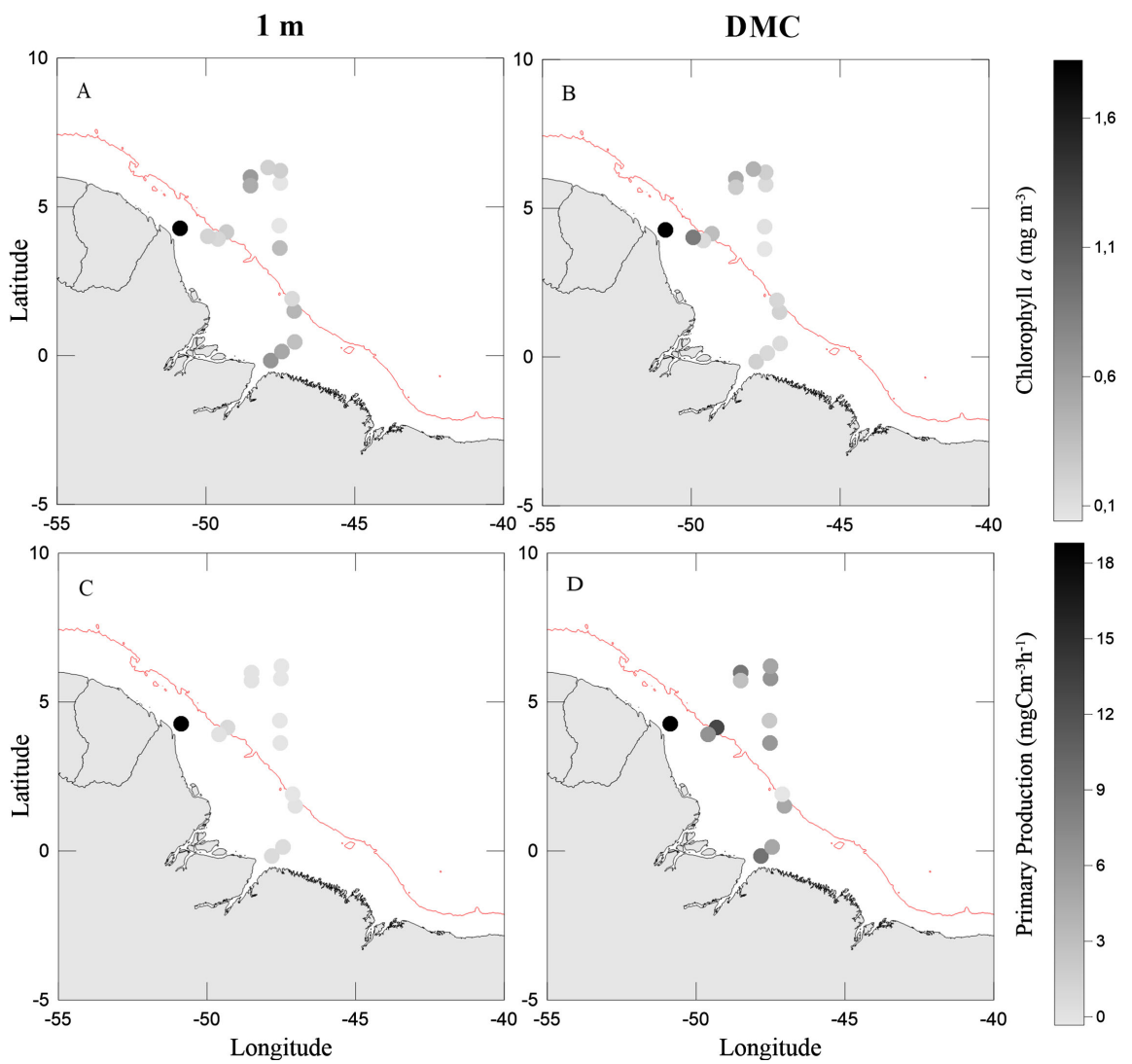

Figure 5. Distribution of (A) Chlorophyll $a$ at surface, (B) Chlorophyll $a$ at DCM, (C) Primary Production at surface and (D) Primary Production at DCM, during the CFV cruise, September 2014.

\section{Discussion}

Fluvial plumes may extend over long distances and are important areas for biological productivity due to their nutrient supply [41]. The expansion of the Amazon River plume depends not only on its volumetric flow, but also on the dynamics of circulation on its platform as a consequence of the direction and velocity of winds [15]. In the period from February to June, the North Brazil Current (NBC) presents a continuous flow along the Brazilian coast, in the northwest direction, and from July to January, the northward migration of the Southeast trade winds promotes NBC retroflexion, crossing the equator line and feeding the North Equatorial Counter-current (NECC) between latitudes $5^{\circ} \mathrm{N}$ and $10^{\circ} \mathrm{N}$ [7] [30] [31] [32].

In the present study, $\mathrm{ADCP}$ data highlight higher intensity currents directing to the east and incorporating the NECC. This is due to the influence of the NBC retroflexion, which in this period, due to the displacement of the ITCZ (Intertropical Convergence Zone) more to the north, causing current intensification [31] [42] [43] [44]. A similar pattern has been reported by [45], who recorded NBC current velocities above $90 \mathrm{~cm} \cdot \mathrm{s}^{-1}$ in the first $50 \mathrm{~m}$ of depth in September. It is because of this circulation pattern that the Amazon plume shows strong seasonality in its distribution in the tropical Atlantic, being transported towards 
the center of the tropical Atlantic during the second half of the year. During the sampling period of this study (September 2014), the Amazon plume is close to its greatest extent, although it corresponds to the period of lowest river evasion. Thus, stations 11 to 13 have surface salinity significantly lower than that of adjacent ocean waters even though they are located very far from the coast (between $4^{\circ}$ and $6^{\circ} \mathrm{N}$ ). In these oceanic stations characterized by relatively low salinities, shallower halocline and thermocline were observed with depths of approximately 10 to $30 \mathrm{~m}$, corroborating with [14], who reported that in waters influenced by the plume, there is stratification and shallow halocline. However, the region presents another source of freshwater that can significantly alter surface salinity and generate shallow halocline and thermocline: rainfall. ITCZ presents high rainfall throughout the year and during the campaign presented here; ITCZ was in the sampled northern region (Figure 6). Precipitation data interpolated at the position of the sampled stations show that stations 10,11 and 12 are the most affected by precipitation. According to [46] [47], intense rainfall associated with ITCZ increases the extent of surface brackish waters in the region, which spatially coincide with the Amazon plume and may result in overestimation of the plume area by more than $20 \%$ when estimated only based on salinity. The impact of ITCZ on the salinity of the region could thus explain that in stations 11 and 12, the reduced salinity observed is not accompanied by the increase of productivity, chlorophyll $a$ and silicate concentrations in the comparison with sampled ocean waters.

The flows show the direction of the currents to the north with smaller velocity vectors (Figure 3), influencing the phytoplankton productivity distribution, where it is observed that the stations with the highest productivity were the first stations (E1 and E2), E13 corresponding to the platform limit and especially E16, located in the internal platform with approximately $400 \mathrm{~km}$ of distance from the river mouth, the latter two being considered plume waters.

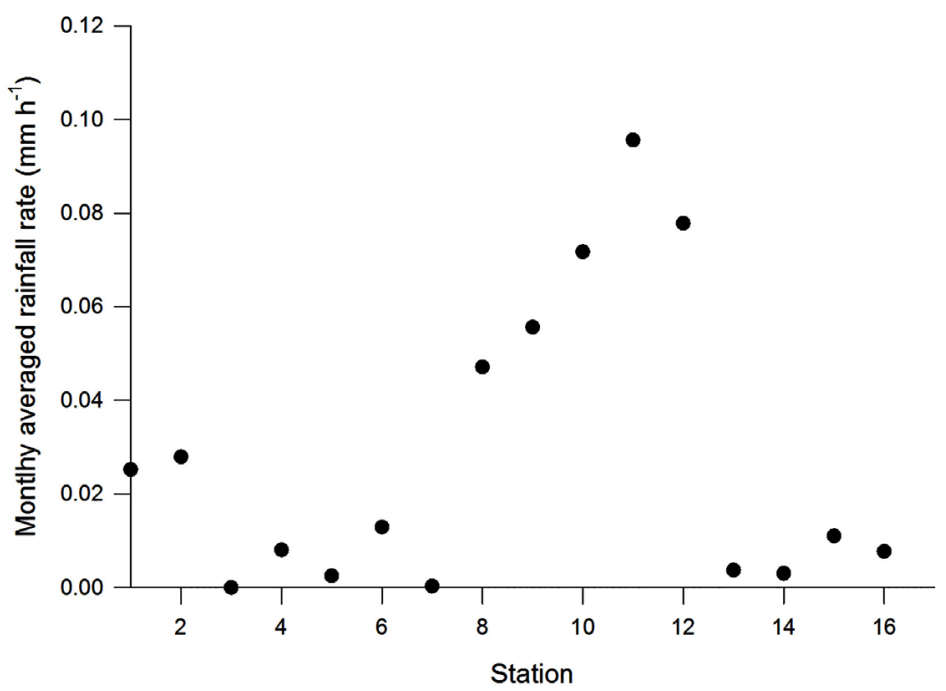

Figure 6. Daily rainfall rate obtained from the TRMM and interpolated at the position of each sampling station during the CFV cruise, September 2014. 
According to the classification of [48], in general, productivities presented in this study are typical of oligotrophic tropical waters, with the exception of E16, which is classified as eutrophic. A similar pattern was reported by [14], who found productivities between 0.02 and $0.13 \mathrm{~g} \mathrm{C} \mathrm{m}^{-2}$ day $^{-1}$ in plume waters and 0.02 to $0.12 \mathrm{~g} \mathrm{C} \mathrm{m}^{-2}$ day a ${ }^{-1}$ in ocean waters. Other work [20], recorded slightly higher values, but there was no significant difference between waters with different salinities, presenting productivities of 0.42 (Low salinity), 0.68 (mesohaline), and $0.70 \mathrm{~g} \mathrm{C} \mathrm{m}^{-2}$ day $^{-1}$ (mean salinity) (oceanic). Other previous research [49], recorded values between 0.01 and $0.86 \mathrm{~g} \mathrm{C} \mathrm{m}^{-2} \mathrm{day}^{-1}$ in the period of greatest river flow (April-May). A more recent work [11], divided the area into three zones based on turbidity and salinity. They found productivity concentrations in zone with salinity $<32$ (transition zone), mean value of $2.61 \mathrm{C} \mathrm{m}^{-2}$ day $^{-1}$ and in the oceanic zone (salinity $>32$ ), value of $0.81 \mathrm{C} \mathrm{m}^{-2}$ day $^{-1}$ in the period of minimum discharge, and for the maximum flow period, values of $6.91 \mathrm{C} \mathrm{m}^{-2} \mathrm{day}^{-1}$ were recorded in the transition zone. E16 differs from the other stations because it presents significantly higher primary productivity $\left(28.22 \mathrm{mg} \mathrm{C} \mathrm{m}^{-3} \mathrm{~h}^{-1}\right)$, chlorophyll a $\left(1.83 \mathrm{mg} \cdot \mathrm{m}^{-3}\right)$, silicate $\left(37.20 \mu \mathrm{mol} \cdot \mathrm{L}^{-1}\right)$ and dissolved oxygen values $\left(6.46 \mathrm{~mL} \cdot \mathrm{L}^{-1}\right)$, being typically plume water (salinity of 28 ). These higher silicate concentrations favor a greater development of diatoms in relation to the other groups, a fact reported by [14]. In addition, the high contribution of silicate carried by the plume also supports the association of diatoms with atmospheric $\mathrm{N}_{2}$ fixers, which results in high productivity rates in the plume [20], as found in this station.

Chlorophyll a followed the same pattern of phytoplankton productivity. According to [11], for the minimum discharge period, as found in the present study, similar values of $1.5 \mu \mathrm{g} \cdot \mathrm{l}^{-1}$ were found in the transition zone (salinity < 32 ), corresponding to the area of E16; these high values are expected by the increase in phytoplankton growth due to abrupt variations in water transparency and nutrient availability.

In the other stations with high salinity $(>35)$, the values recorded were similar to those found by [11] (op.cit.), [14] and [20]. For the oceanic region, using the classification of [50], the environment studied during the low discharge period was characterized as oligotrophic, with values $\leq 0.5 \mathrm{mg} \cdot \mathrm{m}^{-3}$.

We included a comparison of different studies that reported primary productivity and chlorophyll-a in this region (Figure 7). The values observed in this study are within the range of values reported by other authors. The standard deviation of primary productivity in the months of August and September is high and can be explained by the wide region studied, including stations near the coast.

Chlorophyll $<20 \mu \mathrm{m}$ (picoplankton) corresponded to more than $50 \%$ of total chlorophyll in almost all sampled stations. According to [51], oligotrophic environments, such as the tropical oceanic zone, are characterized by low chlorophyll a concentrations and generally present small cells (picoplankton). It is important to note that picoplankton may be the main component of phytoplankton 


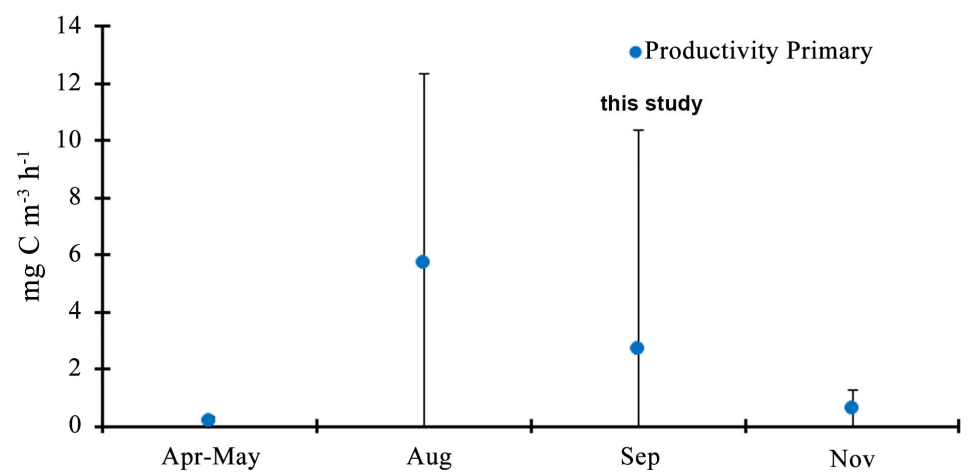

(a)

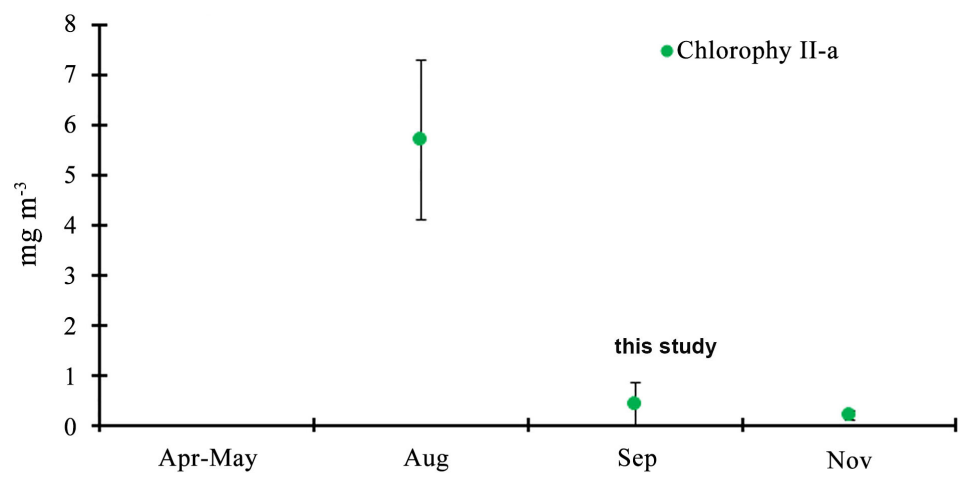

(b)

Months

Figure 7. Primary productivity (a) and chlorophyll-a (b) observed in the study region (average and standard deviation). Apr-May (Teixeira and Tundisi, 1976); Aug (Shipe et al., 2006); Sep (this study); Nov (Smith and DeMaster (1996).

in some places, permanently or temporarily, and this tendency is often related to its great capacity to compete for nutrients and its high tolerance to variations in environmental conditions [52]. The exception to this general pattern is E16, where the microphytoplankton fraction $(>20 \mu \mathrm{m})$ corresponds to $65 \%$.

At stations near the mouth (E1 to E4), there is a slight increase in chlorophyll a concentration and primary production, coinciding with higher MPS concentrations compared to ocean stations (E5 to E9). These stations are close to the coastal region towards the east of the river mouth. This coastal region is highly dynamic and productive, with the largest continuous mangrove system on the planet and submitted to a semidiurnal macro tidal regime with amplitudes around 4 to $6 \mathrm{~m}$, which can determine high export rates of MPS and nutrients, stimulating primary production on the platform, even without the direct participation of the plume (salinity > 35) [19] [53] [54]. In these stations, high amounts of dissolved organic material with terrestrial origin were measured [39], which suggests that the export of coastal material to the platform also contributes significantly to the primary productivity in the region.

In the remaining sampled stations, the MPS concentration was $<2 \mathrm{mg} \cdot \mathrm{L}^{-1}$ including at E16. The Amazon River carries large amounts of suspended matter, 
which severely limits primary productivity and determines that they dominate the heterotrophic processes at the river mouth [39]. However, according to [6], there is a reduction in the turbulence that reduces the capacity of the transport of suspended materials in the platform, thus increasing the light penetration. Other authors, [19] and [55] correlated these high sedimentation rates with high oxygen values due to the increased water transparency, which results in phytoplankton growth. The increase in transparency determines the high primary productivity rates such as those found in this study at station 16 located on the Amazonian platform and transform the plume into a liquid autotrophic system.

From the analysis of data collected in September 2014 on the "Camadas Finas V" oceanographic ship, it is possible to conclude that even considering the minimum discharge period of the Amazon River, the Amazon River plume can reach and influence the oceanographic parameters in the region, including the $4^{\circ}-7^{\circ} \mathrm{N}$ region. This is due to the presence of NBC retroflexion of at this time of the year, promoted by the migration of winds. Thus, higher speeds were measured to the east in the $4^{\circ}-7^{\circ} \mathrm{N}$ region than to the west along the coast. This circulation pattern determines the high area of influence of the Amazon pen at this time of the year.

The transport of the Amazon plume due to the local ocean circulation pattern determines the decrease of the surface salinity, increasing the nutrient content, mainly silicate, the chlorophyll a contents and primary productivity. This transition zone that includes, depending on its discharge period, a very significant area of the continental shelf and oceanic zone, plays an important ecological role for the pelagic community, increasing the productive capacity of the system. However, the results presented here also show that the export of material from the adjacent coast is another determinant of the region productivity, increasing productivity near the coast in this oligotrophic oceanic region.

\section{Conclusions}

The objective of this work was to analyze the distribution of oceanographic parameters, chlorophyll $a$ and primary productivity under the influence of the Amazon River plume, during the period of greatest extension of the Amazon plume. The surface currents along the coast were of lower intensity in the northwest direction, while currents with higher intensities were observed in the east direction, mainly due to the retroflexion of the North Current of Brazil at this time of the year. The spatial influence of the plume was observed in the salinity, although the high precipitation in the region may also have contributed as a source of freshwater. However, the sampled region showed strong negative linear correlation of silicate, chlorophyll $a$ and primary productivity with salinity. The primary productivity and chlorophyll a decrease their values as they move away from the coast.

The values of primary productivity and chlorophyll a observed were similar to those recorded by previous studies in this region. 
The results also suggest that the export of material from the adjacent coastal region is a determinant factor of the productivity of the studied region, mainly due to the geographic extension of the plume of the Amazon River at this time of the year.

\section{Acknowledgements}

The authors would like to thank the scientific and crew members of the NHo. Cruzeiro do Sul-H38 (DHN/Brazilian Navy) for their efforts and dedication during the oceanographic cruise CFV. The Project Prod Pluma-Modelo Regional de Produtividade Primária da Pluma do Amazonas (CNPq grant 460687/2014-0). We are grateful to Keyla Travassos for her help with the analyses of nutrients.

\section{Financial Support}

This work was supported by the Brazilian National Institute of Science and Technology for Tropical Marine Environments-INCT Amb Tropic (CNPq/FAPESB grants 565054/2010-4 and 8936/2011). Camadas Finas 5 cruise were funded by the Brazilian Ministry of Science, Technology and Innovation (MCTI), grants $01 / 2013$.

\section{Conflicts of Interest}

The authors declare no conflicts of interest regarding the publication of this paper.

\section{References}

[1] Andersen, J.H., Schlüter, L. and Ærtebjerg, G. (2006) Coastal Eutrophication: Plankton Recent Developments in Definitions and Implications for Monitoring Strategies. Journal of Plankton Research, 28, 621-628. https://doi.org/10.1093/plankt/fbl001

[2] Smith, V.H. (2007) Using Primary Productivity as an Index of Coastal Eutrophication: The Units of Measurement Matter. Journal of Plankton Research, 29, 1-6. https://doi.org/10.1093/plankt/fbl061

[3] Koening, M.L. and Eskinazi-Leça, E. (1991) Aspectos quantitativos do fitoplâncton na área estuarine de Suape (Pernambuco). In Anais $4^{\circ}$ Encontro Brasileiro de Plâncton, Universidade Federal de Pernambuco, Recife, 55-60.

[4] Kourafalou, V.H., Oey, L.Y., Wang, J.D. and Lee, T.N. (1996) The Fate of River Discharge on the Continental Shelf. 1. Modeling the River Plume and the Inner Shelf Coastal Current. Journal of Geophysical Research, 101, 3415-3434. https://doi.org/10.1029/95JC03024

[5] Trochimczuk Fo, A. and Schettini, C.A.F. (2003) Avaliação da dispersão espacial da pluma do estuário do rio Itajaí-Açu em diferentes períodos de descarga. Notas técnicas Facimar, 7, 83-96.

[6] Dagg, M., Benner, R., Lohrenz, S. and Lawrence, D. (2004) Transformation of Dissolved and Particulate Materials on Continental Shelves Influenced by Large Rivers: Plume Processes. Continental Shelf Research, 24, 833-858. https://doi.org/10.1016/j.csr.2004.02.003 
[7] Foster, A.R., Subramaniam, A., Mahaffey, C., Carpenter, E.J., Capone, D.G. and Zehr, J.P. (2007) Influence of the Amazon River Plume on Distributions of Free-Living and Symbiotic Cyanobacteria in the Western Tropical North Atlantic Ocean. Limnology and Oceanography, 52, 517-532. ps://doi.org/10.4319/lo.2007.52.2.0517

[8] Wisser, D., Fekete, B.M., Vörösmarty, C.J. and Schumann, A.H. (2010) Reconstructing $20^{\text {th }}$ Century Global Hydrography: A Contribution to the Global Terrestrial Network-Hydrology (GTN-H). Hydrology and Earth System Sciences, 14, 1-24. https://doi.org/10.5194/hess-14-1-2010

[9] Goes, I.J., Gomes, H.R., Chekalyuk, A.M., Carpenter, E.J., Montoya, J.P., Coles, V.J., Yager, P.L., Berelson, W.M., Capone, D.G., Foster, R.A., Steinberg, D.K., Subramaniam, A., Grasshoff, K., Ehrhardt, M. and Kremling, K. (1983) Methods of Seawaters Analysis. 2nd Edition, Verlag Chemie, Deerfield Beach, Florida, 419.

[10] Lentz, S. and Limeburner, R. (1995) The Amazon River Plume during AMASSEDS: Spatial Characteristics and Salinity Variability. Journal of Geophysical Research, 100, 2355-2375. https://doi.org/10.1029/94JC01411

[11] Smith Jr., W.O. and DeMaster, D.J. (1996) Phytoplankton Biomass and Productivity in the Amazon River Plume: Correlation with Seasonal River Discharge. Continental Shelf Research, 16, 291-319. https://doi.org/10.1016/0278-4343(95)00007-N

[12] Cai, W.-J., Chen, C.T.A. and Borges, A. (2013) Carbon Dioxide Dynamics E Fluxes in Coastal Waters Influenced by River Plumes. In: Biogeochemical Dynamics at Major River-Coastal Interfaces, Cambridge University Press, Cambridge, 155-173. https://doi.org/10.1017/CBO9781139136853.010

[13] Ibánhez, J.S.P., Diverrès, D., Araujo, M. and Lefèvre, N. (2015) Seasonal and Interannual Variability of Sea-Air $\mathrm{CO}_{2}$ Fluxes in the Tropical Atlantic Affected by the Amazon River Plume. Global Biogeochemical Cycles, 29, 1640-1655. https://doi.org/10.1002/2015GB005110

[14] Shipe, R.F., Curtaz, J., Subramaniam, A., Carpenter, E.J. and Capone, D.G. (2006) Diatom Biomass and Productivity in Oceanic and Plume-Influenced Waters of the Western Tropical Atlantic Ocean. Deep-Sea Research I, 53, 1320-1334. https://doi.org/10.1016/j.dsr.2006.05.013

[15] Smith Jr., W.O. and Russel, G.J. (1995) Phytoplankton Biomass and Nutrient Distributions in the Amazons River Plume: Environmental Correlates. Geo-Marine Letters, 15, 195-198. https://doi.org/10.1007/BF01204463

[16] DeMaster, D.J., Smith Jr., W.O., Nelson, D.M. and Aller, J.Y. (1996) Biogeochemical Processes in Amazon Shelf Waters: Chemical Distributions and Uptake Rates of Silicon, Carbon and Nitrogen. Continental Shelf Research, 16, 617-643. https://doi.org/10.1016/0278-4343(95)00048-8

[17] Nittrouer, C.A. and DeMaster, D.J. (1996) The Amazon Shelf Setting: Tropical, Energetic, and Influenced by a Large River. Continental Shelf Research, 16, 553-573. https://doi.org/10.1016/0278-4343(95)00069-0

[18] Subramaniam, A., Yager, P.L., Carpenter, E.J., Mahaffey, C., Björkman, K., Cooley, S., Kustka, A.B., Montoya, J.P., Sañudo-Wilhelmy, S.A., Shipe, R. and Capone, D.G. (2008) Amazon River Enhances Diazotrophy and Carbon Sequestration in the Tropical North Atlantic Ocean. Pinas, 105, 10460-104655. https://doi.org/10.1073/pnas.0710279105

[19] Santos, M.L.S., Medeiros, C., Muniz, K., Feitosa, F.A.N., Schwamborn, R. and Macedo, S.J. (2008) Influence of the Amazon and Para Rivers on Water Composition and Phytoplankton Biomass on the Adjacente Shelf. Journal of Coastal Research, 
24, 585-593. https://doi.org/10.2112/05-0538.1

[20] Santos, M.L.S., Muniz, K., Barros-Neto, B. and Araujo, M. (2008) Nutrient and Phytoplankton Biomass in the Amazon River Shelf Waters. Anais da Academia Brasileira de Ciências, 80, 703-717. https://doi.org/10.1590/S0001-37652008000400011

[21] Araujo, M., Noriega, C., Hounsou-gbo, G.A., Veleda, D., Araujo, J., Bruto, L., Feitosa, F., Flores-Montes, M., Lefèvre, N., Melo, P., Otsuka, A., Travassos, K., Schwamborn, R. and Neumann-Leitão, S. (2017) A Synoptic Assessment of the Amazon River-Ocean Continuum during Boreal Autumn: From Physics to Plankton Communities and Carbon Flux. Frontiers in Microbiology, 8, 1358. https://doi.org/10.3389/fmicb.2017.01358

[22] DeMaster, D.J. and Pope, R. (1996) Nutrient Dynamics in Amazon Shelf Waters: Results from AmasSeds. Continental Shelf Research, 16, 263-289. https://doi.org/10.1016/0278-4343(95)00008-O

[23] Nittrouer, C.A., Demaster, D.J., Figueiredo, A.G. and Rine, J.M. (1991) AmasSeds: An Interdisciplinary Investigation of a Complex Coastal Environment. Oceanography, 4, 3-7. https://doi.org/10.5670/oceanog.1991.14

[24] Knoppers, B., Ekau, W., Junior, A.G.F. and Soares-Gomes, A. (2002) Zona Costeira e Plataforma Continental do Brasil. In: Crespor, R. and Soares-Gomes, A., Eds., Biologia Marinha, 2nd Edition, Editora Interciência, Rio de Janeiro.

[25] de Souza, D.C.C. (2010) Caracterização morfológica e sedimentar do talude continental (foz do Amazonas). MSc Dissertation, Universidade Federal do Rio Grande do Norte, Natal.

[26] Brandini, F.P., Lopes, R.M., Gutseit, K.S., Spach, H.L. and Sassi, R. (1997) Planctolologia na plataforma continental do Brasil. Diagnose e revisão bibliográfica. MMA-CIRM-FEMAR, Rio de Janeiro, 196 p.

[27] Coutinho, P.N. (2000) Oceanografia geológica. In: Coutinho, P.N., Ed., Levantamento do Estado da Arte da Pesquisa dos Recursos Vivos Marinhos do Brasil, MMA, SMA, Brasília, 75.

[28] Silveira, I.C.A., Brown, W.S. and Flierl, G. (2000) Dynamics of the North Brazil Current Retroflection Region from the WESTRAX Observations. Journal of Geophysical Research, 99, 28559-28583. https://doi.org/10.1029/2000JC900129

[29] da Silva, A.C., Santos, M.L.S., Araujo, M.C. and Bourlès, B. (2009) Observações hidrológicas e resultados de modelagem no espalhamento sazonal e espacial da pluma de água Amazônica. Acta Amazonica, 39, 361-370. https://doi.org/10.1590/S0044-59672009000200014

[30] Flagg, C.N., Gordon, R.L. and Mcdowell, S. (1986) Hydrographic and Current Observations on the Continental Slope and Shelf of the Western Equatorial Atlantic. Journal of Physical Oceanography, 16, 1412-1429. https://doi.org/10.1175/1520-0485(1986)016<1412:HACOOT>2.0.CO;2

[31] Muller-Karger, F.E., Richardson, P.L. and Mcgillicudy, D. (1995) On the Offshore Dispersal of the Amazon's Plume in the North Atlantic: Comments on the Paper by A. Longhurts, "Seasonal Cooling and Blooming in the Tropical Oceans". Deep-Sea Research, 42, 2127-2173. https://doi.org/10.1016/0967-0637(95)00085-2

[32] Ffield, A. (2005) North Brazil Current Rings Viewed by TRMM Microwave Imager SST and the Influence of the Amazon Plume. Deep-Sea Research, 52, 137-160. https://doi.org/10.1016/j.dsr.2004.05.013

[33] Strickland, J.D.H. and Parsons, T.R. (1972) A Pratical Handbook of Seawaters 
Analysis. Bulletin Fisheries Research Board of Canada, 167, 207-211.

[34] Grasshoff, K., Ehrardt, M. and Kremling, K. (1983) Methods of Seawater Analysis. 2th Edition, Velag Chemie, New York.

[35] UNESCO (1966) Determination of Photosynthetic Pigments in Sea Waters. Report of SCOR/UNESCO Working Group 17 with Meat from 4 to 6 June 1964, Monographys on Oceanology Methodology, Paris, 66 p.

[36] Parsons, T.R. and Strickland, J.D.H. (1963) Discussion of Spectrophometria Determination of Marine-Plant Pigments, with Revised Equations for Ascertaining Clorophyll $a$ and Carotenoids. Journal of Marine Research, 21, 155-163.

[37] Steemann-Nielsen, E. (1952) The Use of Radioactive Carbon (C14) for Measuring Organic Production in the Sea. Journal du Conseil Permanent International pour L'Exploration de el Mer, Copenhagen, 18, 117-140. https://doi.org/10.1093/icesjms/18.2.117

[38] Teixeira, C. (1973) Introdução aos métodos para medir a produção primária do fitoplâncton marinho. Boletim Instituto Oceanográfico Universidade de São Paulo, 22, 8-92. https://doi.org/10.1590/S0373-55241973000100004

[39] Lefèvre, N., Flores Montes, M., Gaspar, F.L., Rocha, C., Jiang, S., de Araújo, M.C. and Ibánhez, J. (2017) Net Heterotrophy in the Amazon Continental Shelf Changes Rapidly to a Sink of $\mathrm{CO}_{2}$ in the Outer Amazon Plume. Frontiers in Marine Science, 4, 278. https://doi.org/10.3389/fmars.2017.00278

[40] Huffman, G.J., Adler, R.F., Bolvin, D.T., Gu, G., Nelkin, E.J., Bowman, K.P. and Wolff, D.B. (2007) The TRMM Multisatellite Precipitation Analysis (TMPA): Quasi-Global, Multiyear, Combined-Sensor Precipitation Estimates at Fine Scales. Journal of Hydrometeorology, 8, 38-55. https://doi.org/10.1175/JHM560.1

[41] Kang, Y., Pan, D., Bai, Y., He, X., Chen, X., Chen, C.T.A. and Wang, D. (2013) Area of the Global Major River Plumes. Acta Oceanologica Sinica, 32, 79-88. https://doi.org/10.1007/s13131-013-0269-5

[42] Silveira, I.C.A., Miranda, L.B. and Brown, W.S. (1994) On the Origins of the North Brazil Current. Journal of Geophysical Research, 105, 22501-22512. https://doi.org/10.1029/94JC01776

[43] Schott, F.A., Fischer, J. and Stramma, L. (1998) Transports and Pathways of the Upper-Layer Circulation in the Western Tropical Atlantic. Journal of Physical Oceanography, 28, 1904-1928. https://doi.org/10.1175/1520-0485(1998)028<1904:TAPOTU>2.0.CO;2

[44] Wilson, W.D., Johns, W.E. and Garzoli, S.L. (2002) Velocity Structure of North Brazil Current Rings. Geophysical Research Letters, 29, Article No. 1273. https://doi.org/10.1029/2001GL013869

[45] Bourlès, B., Gouriou, Y. and Chuchla, R. (1999) On the Circulation in the Upper Layer of the Western Equatorial Atlantic. Journal of Geophysical Research, 104, 21.151-21.170. https://doi.org/10.1029/1999JC900058

[46] Ibánhez, J.S.P., Araujo, M. and Lefèvre, N. (2016) The Overlooked Tropical Oceanic $\mathrm{CO}_{2}$ Sink. Geophysical Research Letters, 43, 3804-3812. https://doi.org/10.1002/2016GL068020

[47] Coles, V.J., Brooks, M.T., Hopkins, J., Stukel, M.R., Yager, P.L. and Hood, R.R. (2013) The Pathways e Properties of the Amazon River Plume in the Tropical North Atlantic Ocean. Journal Geophysical Research: Oceans, 118, 6894-6913.

[48] Tundisi, J.G. and Tundisi, T.M. (1976) Produção orgância em ecossistemas aquáticos. Ciência e Cultura, 28, 864-887. 
[49] Teixeira, C. and Tundisi, J. (1967) Primary Production and Phytoplankton in Equatorial Waters. Bulletin of Marine Science, 17, 884-891.

[50] Lalli, C.M. and Parson, T.R. (2006) Biological Oceanography: An Introduction. 2nd Edition, Elsevier, Amsterdam, 314.

[51] Gianesella, S.M. and Saldanha-Corrêa, F.M.P. (2008) Variabilidade e distribuição do séston e da biomassa fitoplanctônica. In: Pires-Vanin, A.M.S., Ed., Oceanografia de um ecossistema subtropical: Plataforma de São Sebastião, SP, Edusp, São Paulo, 205-222.

[52] Lourenço, S.O. and Marques, N.A. (2009) Produção primária marinha. In: Biologia Marinha, 2nd Edition, Interciência, Rio de Janeiro, Cap. 6, 111-154.

[53] Gabioux, M., Vinzon, S.B. and Paiva, A.M. (2005) Tidal Propagation over Fluid Mud Layers on the Amazon Shelf. Continental Shelf Research, 25, 113-125. https://doi.org/10.1016/j.csr.2004.09.001

[54] Gallo, M.N. and Vinzon, S.B. (2005) Generation of Overtides and Compound Tides in Amazon Estuary. Ocean Dynamics, 55, 441-448. https://doi.org/10.1007/s10236-005-0003-8

[55] Gessner, F. (1962) Observacões sobre o regime do fosfato no rio Amazonas. Boletim do Museu Pararense Emíliio Goeldi, 1, 73-83. 